\title{
Rising From Floor Test Functional Test
}

National Cancer Institute

\section{Source}

National Cancer Institute. Rising From Floor Test Functional Test. NCI Thesaurus. Code C141687.

A timed function test created by Araujo et al. (2012) that measures the time taken and techniques utilized to sit and rise from the floor with the minimum amount of support as a predictor of overall health and life expectancy. 